\title{
Antimicrobial Activity of Vigna unguiculata L. Walp Seed Oil
}

\author{
Mohammad Ashraduzzaman ${ }^{1,}$, Mohammad Ashraful Alam ${ }^{1}$, Shahanaz Khatun ${ }^{2}$ and \\ Nurul Absar ${ }^{3}$
}

${ }^{1}$ Department of Chemistry, Rajshahi University of Engineering and Technology, Rajshahi-6204, Bangladesh

${ }^{2}$ Department of Biochemistry and Molecular Biology, University of Rajshahi, Rajshahi-6205, Bangladesh

${ }^{3}$ Department of Biochemistry \& Biotechnology, University of Science and Technology Chittagong (USTC), Foy's Lake, Chittagong-4202, Bangladesh

\begin{abstract}
The antimicrobial activity of three varieties of Vigna unguiculata L. Walp seed oil (LBS-1, LBS-2 and LBS-3) were investigated against five Gram positive bacteria (Bacillus megaterium, Bacillus subtilis, Sarcina lutea, Salmonella typhi and Staphylococcus aureus) and four Gram negative (Escherichia coli, Shigella dysenteriae, Shigella sonnei, Shigella shiga) and four fungi (Penicilium spp., Mucor spp., Candida albicans and Aspergillus fumigatius). The LBS-1 oil at the concentration of $400 \mu \mathrm{g} /$ disc showed the highest activity against Sarcina lutea $(19 \pm 0.1 \mathrm{~mm})$ than that of LBS-2 $(14 \pm 0.3 \mathrm{~mm})$ and LBS-3 $(12 \pm 0.3 \mathrm{~mm})$ oil whereas LBS-3 oil showed highest activity against Staphylococcus aureus $(16 \pm 0.1 \mathrm{~mm})$ than that of LBS-1 $(10 \pm 0.6 \mathrm{~mm})$ and LBS-2 $(13 \pm 0.4 \mathrm{~mm})$ oil. All the three oils are active against the three tested fungi namely Penicilium spp., Mucor spp. and Candida albicans but showed no sensitivity against Aspergillus fumigatius.
\end{abstract}

Keywords: Plant oil, seed oil, Vigna unguiculata, antibacteria, antifungi.

\section{INTRODUCTION}

In the treatment of infectious diseases, microorganisms have developed resistance to many antibiotics [1]. The increasing resistance to microorganisms forced scientists to the search for new infection-fighting substances from various sources [2]. By a number of studies worldwide, the antimicrobial properties of plants have been investigated and because of their antimicrobial properties, many of them have been used as therapeutic alternatives [3]. The plants such as Orthosiphon stamineus Benth [4], Coccinia grandis L. [5], Moringa oleifera L. [6], Calotropis gigantean L. [7], Callistemon viminalis [8], Diospyros peregrine, Coccinia grandis, and Swietenia macrophylla [9] exhibits antimicrobial activity.

The plant Vigna unguiculata L. Walp (Bengali name: Barbati, English name: Cowpea), grows widely in Asia, Africa and South America [10]. By mixing seed powder with oil, it is used as medicine of stubborn boils [11]. The seed is diuretic and also used to strengthen the stomach. Boiled seeds are eaten to destroy worms in the stomach [12]. Powdered roots are eaten with porridge to treat chest pain, epilepsy and painful menstruation, [13]. Physico-chemical Properties and Enzyme contents of Vigna unguiculata L. Walp seeds [14], Extraction and Characterization of Vigna unguiculata L. Walp seed oil [15] and Antidiabetic

*Address correspondence to this author at the Department of Chemistry, Rajshahi University of Engineering and Technology, Rajshahi-6204, Bangladesh; Tel: +880721751320-1(543); Fax: +880721-750834;

E-mail: ashraduzzaman16@gmail.com effects of Vigna unguiculata L. Walp seed oil have been investigated [16]. This seed is rich in oil and contain some essential fatty acids [15]. Many seed oils exhibit antimicrobial activity have been reported [1719]. Antimicrobial activity of Vigna unguiculata leaf extracts of acetone and ethanol against several fungal and bacterial strains have also been reported [20]. However, as far as the literature is concerned, no report on the antimicrobial activity of Vigna unguiculata L. Walp seed oil has found thus far. Hence the present study was undertaken to investigate the role of $V$. unguiculata seed oil as a potential antibacterial and antifungal agent.

\section{MATERIALS AND METHODS}

\section{Collection of Seeds}

Ripe pods of barbati (Vigna unguiculata L. Walp) used in this work were collected from the experimental at Rajshahi city, Rajshahi, Bangladesh in the year 2007. The authenticity of the barbati was identified by Professor A.T.M. Naderuzzaman, Department of Botany and University of Rajshahi, Bangladesh. The varieties reported herein, which were all cultivated in homogeneous conditions and different morphologically from each other, were: LBS-1 (pods are short, straight and red; seeds are somewhat round, small, smooth and red), LBS-2 (pods are long, sylindrical and deep green; seeds are somewhat elongated, kidney shaped, and deep red), and LBS-3 (pods are short, somewhat curved and light green; seeds are small, kidney shaped and red), To remove the foreign materials, the seeds 
were separated manually from the flesh of the fruits and washed several times with water. Afterward, the seeds were dried in the sunlight for four consecutive days and again in an electric oven at $40^{\circ} \mathrm{C}$ until a constant weight were reached. The seeds were ground to a fine powder, packed and stored in a refrigerator at $4^{\circ} \mathrm{C}$ prior to analysis.

\section{Extraction of Oil from Seed}

For solvent extraction (Soxhlet method), $500 \mathrm{~g}$ of ground barbati seeds were placed into a cellulose paper cone and extracted using $\mathrm{n}$-Hexane in a $5-\mathrm{I}$ Soxhlet extractor for $8 \mathrm{~h}$ [21]. By using rotary evaporator the oil was recovered and the residual solvent was removed by drying in an oven at $60{ }^{\circ} \mathrm{C}$ for $1 \mathrm{~h}$.

\section{Test Microorganisms}

Nine pathogenic bacteria were selected for the antibacterial activity test, five of which were gram positive (Bacillus megaterium, Bacillus subtilis, Sarcina lutea, Salmonella typhi and Staphylococcus aureus) and the remaining were gram negative (Escherichia coli, Shigella dysenteriae, Shigella sonnei, Shigella shiga) and four fungi (Penicilium ssp., Mucor spp. Candida albicans and Aspergillus fumigatius). The pure cultures were collected from the microbiological research laboratory, Institute of Biological Sciences (IBSc), Rajshahi University.

\section{Antimicrobial Study}

The bacterial and fungal strains were cultured in nutrient Agar medium and Dextrose Agar medium respectively for 12 and $24 \mathrm{hrs}$. The antibacterial activity of leaf extracts were tested by disc diffusion assay method [22]. The Nutrient Agar plates used for antibacterial tests were incubated at $37^{\circ} \mathrm{C}$ for $24 \mathrm{hrs}$ whereas the Dextrose Agar plates for antifungal tests were incubated at $30^{\circ} \mathrm{C}$ for $72 \mathrm{hrs}$. In nutrient agar plates, an inoculums size, $10^{6} \mathrm{cfu} / \mathrm{ml}$ for bacteria was used and on dextrose agar plates $2 \times 10^{5}$ spores were used for fungi. As positive control, Doxycycline is used for antibacterial tests whereas Nystatin is used as positive control for antifungal tests. Antifungal and antibacterial activity was determined by measuring the diameter of the zone of inhibition (Mean \pm SD) surrounding fungal and bacterial growth.

\section{RESULTS AND DISCUSSION}

\section{Results}

The antibacterial activity of LBS-1 oil, LBS-2 oil and LBS-3 oil were tested against nine bacteria at concentrations of $200 \mu \mathrm{g} / \mathrm{disc}$ and $400 \mu \mathrm{g} / \mathrm{disc}$. Standard antibiotic disc Doxycycline (DXT-30 $\mu \mathrm{g} / \mathrm{disc}$ ) was used for comparison. The results obtained are shown in Tables 1, 2, 3.

The produced zone of inhibition for LBS-1 oil against Bacillus megatorium, Bacillus subtilis, Sarcina lutia, Staphylococcus aureus, Escherichia colli, Shigella dysenteriae, Shigella sonnei and Shigella shiga were $12 \pm 0.2,12 \pm 0.3,19 \pm 0.1,10 \pm 0.6,11 \pm 0.1,12 \pm 0.3$, $11 \pm 0.4$ and $8 \pm 0.1 \mathrm{~mm}$ at $400 \mu \mathrm{g} /$ disc dose respectively. At $200 \mu \mathrm{g} / \mathrm{disc}$ dose, the produced zone of inhibition against the bacteria, Bacillus megatorium, Bacillus subtilis, Sarcina lutia, Escherichia colli and Shigella dysenteriae were $6 \pm 0.3,8 \pm 0.1,10 \pm 0.5,7 \pm 0.2$ and

Table 1: In Vitro Antibacterial Activity of LBS-1 Oil and Doxycycline

\begin{tabular}{|c|c|c|c|}
\hline \multirow[t]{2}{*}{ Test bacteria } & \multicolumn{3}{|c|}{ Zone of inhibition (diameter in $\mathrm{mm}$.) } \\
\hline & Oil $200 \mu \mathrm{g} / \mathrm{disc}($ le 200) & Oil $400 \mu \mathrm{g} / \mathrm{disc}$ (le 400) & Doxycycline ( $\mu \mathrm{g} / \mathrm{disc})$ \\
\hline \multicolumn{4}{|l|}{ Gram positive } \\
\hline Bacillus megatorium & $6 \pm 0.3$ & $12 \pm 0.2$ & $29 \pm 0.1$ \\
\hline Bacillus subtilis & $8 \pm 0.1$ & $12 \pm 0.3$ & $25 \pm 0.4$ \\
\hline Sarcina lutia & $10 \pm 0.5$ & $19 \pm 0.1$ & $27 \pm 0.2$ \\
\hline Salmonella typhi & - & - & $26 \pm 0.1$ \\
\hline Staphylococcus aureus & - & $10 \pm 0.6$ & $26 \pm 0.2$ \\
\hline \multicolumn{4}{|l|}{ Gram negative } \\
\hline Escherichia colli & $7 \pm 0.4$ & $11 \pm 0.1$ & $28 \pm 0.3$ \\
\hline Shigella dysenteriae & $9 \pm 0.2$ & $12 \pm 0.3$ & $25 \pm 0.1$ \\
\hline Shigella sonnei & - & $11 \pm 0.4$ & $28 \pm 0.1$ \\
\hline Shigella shiga & - & $8 \pm 0.1$ & $30 \pm 0.5$ \\
\hline
\end{tabular}

LBS $=$ Local Barbati Seed. Results are presented as average-means \pm standard mean deviations $(n=4)$. 
Table 2: In Vitro Antibacterial Activity of LBS-2 Oil and Doxycycline

\begin{tabular}{|c|c|c|c|}
\hline Test bacteria & \multicolumn{3}{|c|}{ Zone of inhibition (diameter in $\mathrm{mm}$.) } \\
\hline \multicolumn{4}{|l|}{ Gram positive } \\
\hline Bacillus megatorium & $5 \pm 0.5$ & $11 \pm 0.4$ & $29 \pm 0.3$ \\
\hline Bacillus subtilis & $6 \pm 0.1$ & $11 \pm 0.1$ & $25 \pm 0.1$ \\
\hline Staphylococcus aureus & - & $13 \pm 0.4$ & $26 \pm 0.1$ \\
\hline \multicolumn{4}{|l|}{ Gram negative } \\
\hline Escherichia colli & $6 \pm 0.1$ & $10 \pm 0.1$ & $28 \pm 0.5$ \\
\hline Shigella dysenteriae & $8 \pm 0.3$ & $10 \pm 0.3$ & $25 \pm 0.2$ \\
\hline
\end{tabular}

LBS $=$ Local Barbati Seed. Results are presented as average-means \pm standard mean deviations $(n=4)$.

Table 3: In Vitro Antibacterial Activity of LBS-3 Oil and Doxycycline

\begin{tabular}{|c|c|c|c|}
\hline Test bacteria & \multicolumn{3}{|c|}{ Zone of inhibition (diameter in $\mathrm{mm}$.) } \\
\hline \multicolumn{4}{|l|}{ Gram positive } \\
\hline Bacillus megatorium & $8 \pm 0.1$ & $12 \pm 0.4$ & $29 \pm 0.4$ \\
\hline Bacillus subtilis & $9 \pm 0.2$ & $11 \pm 0.1$ & $25 \pm 0.1$ \\
\hline Staphylococcus aureus & - & $16 \pm 0.1$ & $26 \pm 0.5$ \\
\hline \multicolumn{4}{|l|}{ Gram negative } \\
\hline Escherichia colli & $5 \pm 0.4$ & $10 \pm 0.6$ & $28 \pm 0.4$ \\
\hline Shigella dysenteriae & $8 \pm 0.1$ & $11 \pm 0.5$ & $25 \pm 0.1$ \\
\hline
\end{tabular}

LBS $=$ Local Barbati Seed. Results are presented as average-means \pm standard mean deviations $(n=4)$.

$9 \pm 0.2 \mathrm{~mm}$ respectively but this amount of oil has no activity against the bacteria such as Staphylococcus aureus, Shigella sonnei and Shigella shiga while it showed no activity against Salmonella typhi in both the concentration of oil. From the observation it was found that the $400 \mu \mathrm{g} / \mathrm{disc}$ dose is more potent on Sarcina lutia, $(19 \pm 0.1)$.

The produced zone of inhibition for LBS-2 oil against Bacillus megatorium, Bacillus subtilis, Sarcina lutia, Staphylococcus aureus, Escherichia colli, Shigella dysenteriae, Shigella sonnei and Shigella shiga were $11 \pm 0.4,11 \pm 0.1,14 \pm 0.3,13 \pm 0.4,10 \pm 0.1,10 \pm 0.3$, $11 \pm 0.1$ and $6 \pm 0.5 \mathrm{~mm}$ at $400 \mu \mathrm{g} /$ disc dose respectively.
At $200 \mu \mathrm{g} /$ disc dose, the produced zone of inhibition against the bacteria, Bacillus megatorium, Bacillus subtilis, Sarcina lutia, Escherichia colli and Shigella dysenteriae were $5 \pm 0.5,6 \pm 0.1,8 \pm 0.4,6 \pm 0.1$ and $8 \pm 0.3$ $\mathrm{mm}$ respectively but this amount of oil has no activity against the bacteria such as Staphylococcus aureus, Shigella sonnei and Shigella shiga. Like LBS-1, LBS-2 oil has no activity against Salmonella typhi.

The produced zone of inhibition for LBS-3 oil against Bacillus megatorium, Bacillus subtilis, Sarcina lutia, Staphylococcus aureus, Escherichia colli, Shigella dysenteriae, Shigella sonnei and Shigella shiga were $12 \pm 0.4,11 \pm 0.1,12 \pm 0.3,16 \pm 0.1,10 \pm 0.6,11 \pm 0.5$, 
Table 4: In vitro Antifungal Activities of LBS-1, LBS-2 and LBS-3 Oil and Nystatin

\begin{tabular}{|c|c|c|c|c|c|c|c|}
\hline \multirow[t]{3}{*}{ Test fungi } & \multicolumn{6}{|c|}{ Zone of inhibition (diameter in $\mathrm{mm}$.) } & \multirow{3}{*}{$\begin{array}{c}\text { Nystatin } \\
(100 \mu \mathrm{g} / \text { disc })\end{array}$} \\
\hline & \multicolumn{2}{|c|}{ Oil of LBS-1 } & \multicolumn{2}{|c|}{ Oil of LBS-2 } & \multicolumn{2}{|c|}{ Oil of LBS-3 } & \\
\hline & $\begin{array}{c}(100 \mu \mathrm{g} / \\
\text { disc })\end{array}$ & $\begin{array}{c}(200 \mu \mathrm{g} / \\
\text { disc })\end{array}$ & $\begin{array}{c}(100 \mu \mathrm{g} / \\
\text { disc })\end{array}$ & $\begin{array}{c}(200 \mu \mathrm{g} / \\
\text { disc })\end{array}$ & $(100 \mu \mathrm{g} / \mathrm{disc})$ & $(200 \mu \mathrm{g} / \mathrm{disc})$ & \\
\hline Penicilium spp. & $11 \pm 0.3$ & $13 \pm 0.5$ & $12 \pm 0.1$ & $14 \pm 0.1$ & $12 \pm 0.4$ & $15 \pm 0.1$ & $25 \pm 0.1$ \\
\hline Mucor spp. & $8 \pm 0.1$ & $9 \pm 0.3$ & $9 \pm 0.3$ & $11 \pm 0.2$ & $9 \pm 0.4$ & $10 \pm 0.2$ & $25 \pm 0.3$ \\
\hline Candida albicans & $9 \pm 0.2$ & $11 \pm 0.1$ & $9 \pm 0.4$ & $10 \pm 0.1$ & $10 \pm 0.3$ & $12 \pm 0.4$ & $23 \pm 0.5$ \\
\hline $\begin{array}{l}\text { Aspergillus } \\
\text { Fumigatius }\end{array}$ & - & - & - & - & - & - & $24 \pm 0.1$ \\
\hline
\end{tabular}

LBS $=$ Local Barbati Seed. Results are presented as average-means \pm standard mean deviations $(n=4)$. '-' no sensitivity.

$11 \pm 0.4$ and $8 \pm 0.1 \mathrm{~mm}$ at $400 \mu \mathrm{g} /$ disc dose respectively. At $200 \mu \mathrm{g} / \mathrm{disc}$ dose, the produced zone of inhibition against the bacteria, Bacillus megatorium, Bacillus subtilis, Sarcina lutia, Escherichia colli and Shigella dysenteriae were $8 \pm 0.1,9 \pm 0.2,10 \pm 0.3,5 \pm 0.4$ and $8 \pm 0.1 \mathrm{~mm}$ respectively but this amount of oil has no activity against the bacteria such as Staphylococcus aureus, Shigella sonnei and Shigella shiga. LBS-3 oil also showed no activity against Salmonella typhi.

The LBS-1 oil at the concentration of $400 \mu \mathrm{g} / \mathrm{disc}$ showed the highest activity against Sarcina lutea $(19 \pm 0.1)$ than that of LBS-2 $(14 \pm 0.3)$ and LBS-3 $(12 \pm 0.3)$ oil whereas LBS-3 oil showed highest activity against Staphylococcus aureus $(16 \pm 0.1)$ than that of LBS-1 (10 \pm 0.6$)$ and LBS-2 (13 \pm 0.4$)$ oil.

The antifungal activities of oil of LBS-1, LBS-2 and LBS-3 against five pathogenic fungi were investigated by using the doses of $100 \mu \mathrm{g} / \mathrm{disc}$ and $200 \mu \mathrm{g} / \mathrm{disc}$. The standard antibiotic disc of nystatin $(100 \mu \mathrm{g} / \mathrm{disc})$ was used for comparison. The results of antifungal activity (zone of inhibition) of test materials against respective fungi were given in the Table 4.

It was found that all the three oils are active against the three tested fungi namely Penicilium spp., Mucor spp. and Candida albicans but showed no sensitivity against Aspergillus fumigatius. All the three varieties of LBS-1, LBS-2 and LBS-3 oil are more active against Penicilium spp., but LBS-3 oil showed the more activity than that of LBS-1 and LBS-2 oil.

\section{DISCUSSION}

By many researchers the antimicrobial activities of various plants and herbs have been reported [23, 24, 25] Various phytochemicals present in plants namely alkaloids, flavonoids, terpinoids and tannins are producing very exciting opportunity for the expansion of modern chemotherapies against a very wide range of microorganisms [26]. The antimicrobial efficacy of plant phenolic compounds against Salmonella and E. coli have been reported [27].The flavonoid aglycones, namely quercetin be present in $V$. unguiculata $L$. is known to inhibit the growth of various fungi and bacteria [28, 29]. A pathway for the development of new antimicrobial agents may be provided by the natural alternative treatments for bacterial and fungal infections.

In the present study a variety of gram positive and gram negative and fungal strain for the screening of antimicrobial effect of three selected seed varieties were selected to perceive the antimicrobial spectrum as well to authenticate ethnomedicinal claims. The results of this study showed that the LBS-1, LBS-2 and LBS-3 oil have varied antimicrobial activities against the tested microorganisms. Among these three varieties, LBS-1 oil at the concentration of $400 \mu \mathrm{g} / \mathrm{disc}$ was found more effective against Sarcina lutia $(19 \pm 0.1)$ followed by LBS-1 and LBS-2 oil. LBS-3 oil at the concentration of $400 \mu \mathrm{g} /$ disc was found more effective against Staphylococcus aureus (16 \pm 0.1$)$ and LBS-3 oil at the concentration of $200 \mu \mathrm{g} / \mathrm{disc}$ was found more effective against Penicilium spp., in order of effectiveness. The seed oil extracted from Cannabis sativa L. posses the antimicrobial activity has also reported [30].

Thus in the search of novel antimicrobial agents, this study has not only scientific basis for some of the therapeutic uses of traditional plant oils, but it also confirmed the ethnomedicinal claims for the selected plants.

\section{CONCLUSION}

From the above experiment it has been found that $V$. unguiculata seed oil might have some 
phytochemicals, which are responsible for the antimicrobial activity. Finally it can conclude that $V$. unguiculata seed oil may be considered as the medicine for diarrhea and dysentery and can be useful as probiotics or as the sources of antifungal agents.

\section{ACKNOWLEDGEMENT}

The authors are grateful to the Chairman of the Department of Biochemistry and Molecular Biology, Rajshahi University, Rajshahi-6205, Bangladesh and to the Chairman of the Department of Chemistry, Rajshahi University of Engineering and Technology, Rajshahi-6205, Bangladesh to give the lab facility to complete this research work.

\section{REFERENCES}

[1] Davis J. Inactivation of antibiotics and the dissemination of resistance gene. Sciences 1994; 264: 375-382.

[2] Kamaran I, Sahin P, Gulluce M, Oguten H, Songul M, Adiguzed A. Antimicroial activity of aqueous and methanol extracts of Juniperus oxycedrus L. J Ethnopharmacol 2003; 2837: 1-5.

[3] Adriana B, Amodovar ANM, Pereira CT, Mariangela TA. Antimicrobial efficacy of Curcuma zedoaria extract as assessed by linear regression compared with commercial mouthrinses. Braz. J Microbiol 2007; 38: 440-445. http://dx.doi.org/10.1590/S1517-83822007000300011

[4] $\mathrm{Ho} \mathrm{CH}$, Noryati I, Sulaiman SF, Rosma A. In vitro antibacterial and antioxidant activities of Orthosiphon stamineus Benth. extracts against food-borne bacteria. Food Chemistry 2010; $122: 1168-1172$. http://dx.doi.org/10.1016/j.foodchem.2010.03.110

[5] Farrukh U, Shareef H, Mahmud S, Ali SA, Rizwani GH. Antimicrobial activities of Coccinia grandis L. Pak J Bot 2008; 40(3): 1259-1262.

[6] Rahman MM, Seikh MMI, Sharmin SA, Islam MS, Rahman MA, Rahman MM, Alam MF. Antimicrobial activity of leaf juice and extracts of Moringa oleifera Lam. Against some human pathogenic bacteria. CMU J Nat Sci 2009; 8(2): 219227.

[7] Alom MA, Habib MR, Nikkon F, Rahman M, Karim MR. Antimicrobial activity of akanda (Calotropis gigantean L.) on some pathogenicbacteria. Bangladesh J Sci Ind Res 2008; 43(3): 397-404.

[8] Dalahaya C, Rainford L, Nicholson A, Mitchel S, Lindo J, Ahmad M. Antibacterial and antifungal analysis of crude extracts from the leaves of Callistemon viminalis. Journal of Medical and Biological Sciences 2009; 3(1): 1-7.

[9] Dewanjee S, Kundu M, Maiti A, Majumdar R, Majumdar A, Mandal SC. In Vitro evaluation of antimicrobial activity of crude extract from plants Diospyros peregrina, Coccinia grandis and Swietenia macrophylla. Trop J Pharm Res 2007; 6: 773-778. http://dx.doi.org/10.4314/tipr.v6i3.14658

[10] NG NQ, Marechal R. Cowpea taxonomy, origin and germplasm. In Cowpea Research, Production and Utilization. SINGH AND RACHIE (Eds) John Wiley and Sons, New York. 1985; pp. 11-21.

[11] Duke JA. Introduction to food legumes. In: Insect Pests of Tropical Food Legumes, S.R. Singh John Wiley \& Sons, (Ed.): Chichester, UK 1990.
[12] Chopra RN, Nayar SI, Chopra IC. Glossary of Indian Medicinal Plants (Including the supplement), New Delhi, Council of Scientific and Industrial Research 1986.

[13] Vanwyk BE, Gericke N. People's Plants: A guide to useful plants of Southern Africa. Briza Publications, Pretoria, South Africa 2000; p. 192.

[14] Ashraduzzaman M, Alam MA, Absar N. A comparative analysis in Physico-Chemical Compositions And Activities of some Enzymes in the three varieties of locally available Barbati (Vigna unguiculata Linn. Walp.) seeds.In. J Sustain Agril Tech 2009; 5(5): 52-56.

[15] Ashraduzzaman M, Alam MA, Khatun S, Banu S, Absar N. Vigna unguiculata Linn. Walp. seed oil exhibiting antidiabetic effects in alloxan induced diabetic rats. Malaysian Journal of Pharmaceutical Sciences 2011; 9(1): 13-23.

[16] Ashraduzzaman M, Alam MA, Khatun S, Luthfunnesa B, Absar N. Extraction and Cherecterization of Cowpea (Vigna unguiculata Linn. Walp.) seed oil. Journal of Science and Technology 2013; 3(2): 431-438.

[17] Hasan NA, Nawahwi MZ, Malek HA. Antimicrobial Activity of Nigella sativa Seed Extract Sains Malaysiana 2013; 42(2): 143-147.

[18] Ibrahim TA, Fagbohun ED. Physicochemical Properties and In vitro Antibacterial activity of Corchorus Olitorius Linn. Seed oil. Life sciences Leaflets 2011; 15: 499-505.

[19] Novak J, Zitterl-Eglseer K, Deans SG, Franz CM. Essential Oils of Different Cultivars of Cannabis sativa L. and their Antimicrobial Activity. Flavour Fragrance Journal 2001; 16(4): 259-262.

http://dx.doi.org/10.1002/ffj.993

[20] Kritzinger Q, Lail N, Aveling TAS. Antimicrobial activity of cowpea (Vigna unguiculata) leaf extracts. South African Journal of Botany 2005; 71: 45-48. http://dx.doi.org/10.1016/S0254-6299(15)30147-2

[21] Pena DG, Anguiano RGL, Arredondo JJM. Modification of the method 1 AOAC (CB-method) for the detection of aflatoxins. Bull Environ Contam Toxicol 1992; 49: 485-489. http://dx.doi.org/10.1007/BF00196287

[22] Vander BDA. Vlietnck. Screening methods for antibacterial and antiviral agents from higher plants. IN: Assay for Bioactivity. (K. Hostiettman Academic Press, London) 1991; p. 47-69.

[23] Cowan MM. Plant products as antimicrobial agents. Clin Microbiol Rev 1999; 12(4): 564-82.

[24] Hediat MH, Salama, Najat M. Antimicrobial activity and phytochemical analyses of Polygonum aviculare L. (Polygonaceae), naturally growing in Egypt. Saudi J Biol Sci 2010; 17(1): 57-63. http://dx.doi.org/10.1016/j.sjbs.2009.12.009

[25] Chea A, Jonville MC, Bun SS, Laget M, Elias R, Duménil G, Balansard G. In vitro Antimicrobial Activity of Plants used in Cambodian Traditional Medicine. Am J Chin Med 2007; 35: 867. http://dx.doi.org/10.1142/S0192415X07005338

[26] Lutterodt GD, Ismail A, Bashear RH, Baharudin HM. Antimicrobial effects of Psidium guajava extracts as one mechanism of its antidiarrhoeal action. Malay J Med Sci 1999; 6(2): 17-20.

[27] Hayriye CK, Melissa C. Newman Antimicrobial efficacy of plant phenolic compounds against Salmonella and Escherichia Coli. Food Bioscience 2015; 11: 8-16. http://dx.doi.org/10.1016/j.fbio.2015.03.002

[28] El-Gammal AA, Mansour RM. Antimicrobial activities of some flavonoid compounds. Zentralbl Mikrobiol 1986; 141(7): 5615. 
[29] Aziz NH, Farag SE, Mousa LA, Abo-Zaid MA. Comparative antibacterial and antifungal effects of some phenolic compounds. http://www.ncbi.nlm.nih.gov/pubmed/9670554 1998; 93(374): 43-54.
[30] Esra MMA, Aisha ZIA, Salwa MEK, Umelkheir MAG. Antimicrobial Activity of Cannabis sativa L. Chinese Medicine 2012; 3: 61-64.

http://dx.doi.org/10.4236/cm.2012.31010

Received on 25-05-2016

Accepted on 27-06-2016

Published on 04-10-2016

DOl: http://dx.doi.org/10.6000/1927-3037.2016.05.03.1

(C) 2016 Ashraduzzaman et al.; Licensee Lifescience Global.

This is an open access article licensed under the terms of the Creative Commons Attribution Non-Commercial License (http://creativecommons.org/licenses/by-nc/3.0/) which permits unrestricted, non-commercial use, distribution and reproduction in any medium, provided the work is properly cited. 